University of Nebraska - Lincoln

DigitalCommons@University of Nebraska - Lincoln

Faculty Publications from the Harold W. Manter Laboratory of Parasitology

1995

\title{
Comparative Morphology of the Scolices and Microtriches Among Five Species of Tetrabothrius (Eucestoda: Tetrabothriidae)
}

\author{
Eric P. Hoberg \\ USDA-ARS, eric.hoberg@ars.usda.gov \\ D. E. Sims \\ University of Prince Edward Island \\ P. H. Odense \\ National Research Council of Canada
}

Follow this and additional works at: https://digitalcommons.unl.edu/parasitologyfacpubs

Part of the Parasitology Commons

Hoberg, Eric P.; Sims, D. E.; and Odense, P. H., "Comparative Morphology of the Scolices and Microtriches Among Five Species of Tetrabothrius (Eucestoda: Tetrabothriidae)" (1995). Faculty Publications from the Harold W. Manter Laboratory of Parasitology. 725.

https://digitalcommons.unl.edu/parasitologyfacpubs/725

This Article is brought to you for free and open access by the Parasitology, Harold W. Manter Laboratory of at DigitalCommons@University of Nebraska - Lincoln. It has been accepted for inclusion in Faculty Publications from the Harold W. Manter Laboratory of Parasitology by an authorized administrator of DigitalCommons@University of Nebraska - Lincoln. 


\title{
COMPARATIVE MORPHOLOGY OF THE SCOLICES AND MICROTRICHES AMONG FIVE SPECIES OF TETRABOTHRIUS (EUCESTODA: TETRABOTHRIIDAE)
}

\author{
E. P. Hoberg, D. E. Sims ${ }^{*}$, and P. H. Odense $\dagger$ \\ United States Department of Agriculture, Agricultural Research Service, \\ Biosystematics and National Parasite Collection Unit, BARC-East \#1180, 10300 Baltimore Avenue, \\ Beltsville, Maryland 20705-2350
}

\begin{abstract}
The structure of the scolex, neck, and adjacent strobila of 5 species of Tetrabothrius was evaluated using low to high magnification scanning electron microscopy. Species-specific patterns and morphotypes (spiniform, papilliform, and filiform) of microtriches were found on the scolices and strobilar tegument of Tetrabothrius (Oriana) affinis, Tetrabothrius (Oriana) filiformis, and Tetrabothrius (Culmenamniculus) laccocephalus; microtriches were absent in Tetrabothrius (Culmenamniculus) cylindraceus and Tetrabothrius (Tetrabothrius) sp. The presence, distribution, and form of microtriches may not be correlated with the subgeneric divisions of Tetrabothrius or the host taxon. Unique patterns do not appear to be shared with other groups of cestodes, particularly other tetraphyllideans. We suggest that the spiniform, filiform, and papilliform types of microtriches may be symplesiomorphic for the Eucestoda.
\end{abstract}

Microtrich-like structures on the holdfasts of tetraphyllidean cestodes have been recognized as potentially significant characters in systematic analyses (Whittaker and Carvajal, 1980; Whittaker et al., 1985). Although genera and species of the Onchobothriidae and Phyllobothriidae have received attention in studies using scanning electron microscopy (SEM) (Caira, 1992; Caira and Ruhnke, 1990, 1991; Ruhnke, 1993, 1994) members of the Tetrabothriidae have yet to be examined.

Morphological studies of the scolices among species of $\mathrm{Te}$ trabothrius Rudolphi, 1819 have included detailed evaluations by Spätlich (1909), Rees (1956), and Andersen and Lysfjord (1982). Considerable information on the configuration of the scolex is also presented by Baer (1954) and Temirova and Skriabin (1978). Observations of Tetrabothrius pauliani Joyeux and Baer, 1954 and Tetrabothrius sp. from penguins involved SEM, but high magnifications were not employed (Andersen and Lysfjord, 1982). Consequently, there is minimal information on the structure of the tegument of the holdfast and strobila among genera and species of the Tetrabothriidae.

In the present study, using SEM, we evaluated the structure of the tegument of the holdfasts and strobila of 5 species of Tetrabothrius from avian and mammalian hosts. A preliminary appraisal is given for the configuration and distributional patterns of microtriches as systematic characters in this group. Microtriches are compared among tetrabothriids and some other tetraphyllideans to further elucidate putative sister group relationships for these taxa (Hoberg, 1987, 1989). In the context of phylogenetic hypotheses for the Eucestoda (Brooks et al., 1991), microtriches found among tetrabothriids are compared with those reported among the major orders of cestodes.

\section{MATERIALS AND METHODS}

Species representing 3 of the 4 subgenera of the genus Tetrabothrius were examined. Specimens of Tetrabothrius (Culmenamniculus) lac-

Received 14 September 1994; revised 15 December 1994; accepted 15 December 1994.

* Department of Anatomy and Physiology, Atlantic Veterinary College, University of Prince Edward Island, Charlottetown, Prince Edward Island, Canada C1A 4P3.

$\uparrow$ National Research Council of Canada, 1411 Oxford Street, Halifax, Nova Scotia, Canada B3H 3Z2. Deceased. cocephalus Spätlich, 1909, Tetrabothrius (Oriana) filiformis Nybelin, 1916, Tetrabothrius (Culmenamniculus) cylindraceus Rudolphi, 1819, and Tetrabothrius (Tetrabothrius) sp. (the latter apparently undescribed) were recovered while alive from hosts recently collected in the field. Specimens were simultaneously killed and fixed in hot $10 \%$ buffered neutral formalin and later transferred to $70 \%$ ethanol for storage. Specimens of Tetrabothrius (Oriana) affinis (Lönnberg, 1891) were also apparently collected while alive, but the original fixative is unknown.

The following material was studied. Tetrabothrius affinis: 8 cestodes from a blue whale, Balaenoptera musculus (Linnaeus), collected at Hawkes Harbor, Labrador $\left(57^{\circ} 13^{\prime} \mathrm{N} ; 55^{\circ} 20^{\prime} \mathrm{W}\right)$ by R. L. Stevenson on 31 July 1951 (USNM 81901). Tetrabothrius laccocephalus: 5 specimens from a greater shearwater, Puffinus gravis (O'Reilly), collected at Gough Island, South Atlantic Ocean $\left(40^{\circ} 21^{\prime} S ; 9^{\circ} 23^{\prime} \mathrm{W}\right)$ by P. G. Ryan on 11 November 1984 (EPH 2270; and USNM 80012). Tetrabothrius filiformis: 10 specimens from a greater shearwater collected at Gough Island (collection data as above; EPH 2267; and USNM 80010). Tetrabothrius (Tetrabothrius) sp.: 2 specimens from a black-legged kittiwake, Rissa tridactyla (Linnaeus) collected at Talan Island, northern Sea of Okhotsk, Russia $\left(59^{\circ} 18^{\prime} \mathrm{N}\right.$; $\left.14^{\circ} 02^{\prime} \mathrm{E}\right)$ by E.P.H. on 23 August 1988 (EPH 3060; USNM 81903). Tetrabothrius cylindraceus: 5 specimens from a blacklegged kittiwake at Talan Island (collection data as above, USNM 81902).

In preparation for SEM, specimens were dehydrated through a graded series of ethanol; warmed in $100 \%$ ethanol to $35 \mathrm{C}$; placed for $1 \mathrm{hr}$ at constant temperature in $1: 1$ ethanol and Peldri ${ }^{\circledR}$ II, a fluorocarbon that may be used as a substitute for critical point drying (Kennedy et al., 1989). Samples were then placed in $100 \%$ Peldri II at $35 \mathrm{C}$ for $1 \mathrm{hr}$. Following infiltration, the samples were cooled to $20 \mathrm{C}$ and then placed in a low vacuum until the Peldri II was completely sublimed. Specimens were mounted on aluminum stubs with double-sided tape, sputter coated with an estimated $100-250 \AA$ of gold, and examined with a JEOL $35 \mathrm{SEM}$ at $25 \mathrm{kV}$ accelerating voltage.

Meristic and structural characteristics apparent in light microscopy of these species have been reported extensively in the literature (Spätlich, 1909; Baer, 1954; Rees, 1956; Temirova and Skriabin, 1978). The following focuses on attributes of microtrich-like structures observed on the tegument of the bothridia, auricles, apical organ, neck, and strobila. Evaluation of the holdfast among species of Tetrabothrius, where complementary, included those regions of the scolex suggested by Caira and Ruhnke (1990) in studies of other tetraphyllideans. Terminology for the structure of microtriches follows Caira and Ruhnke (1990) and Richmond and Caira (1991) and are defined as follows: spiniform = flattened, often blade-like structures with a base substantially wider than the apex; filiform $=$ typically tubular or cylindrical structures of consistent diameter that may vary from relatively short to highly elongate; papilliform $=$ ovoid structures that are typically wider than long. Measurements are presented as length, width, and diameter in micrometers as determined from photomicrographs (with an estimated error of $\pm 10 \%$ ); sample sizes are indicated as $(n=)$; ranges are presented with mean values in parentheses. 


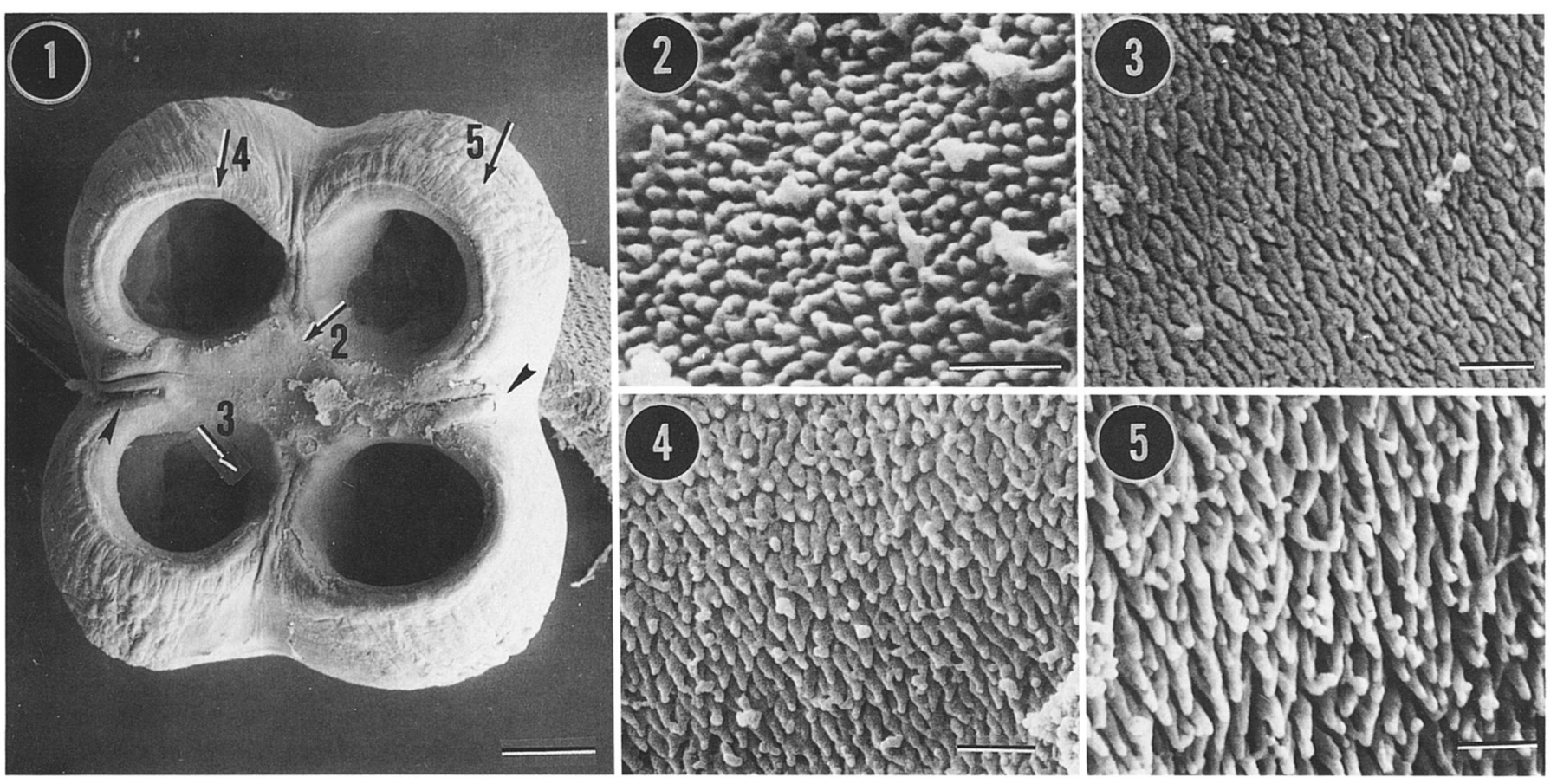

Figures 1-5. Tetrabothrius affinis (scale bars $=500 \mu \mathrm{m}$ for Fig. 1; $1.0 \mu \mathrm{m}$ for Figs. 2-5). 1. Apical view of scolex showing view of apical organ and massive sucker-like bothridia, reduced auricles (pointers), and positions of high magnification views for Figures $2-5$ indicated by arrows. 2. Papilliform to filiform microtriches on apical organ. 3. Spiniform microtriches on adherent surfaces of bothridia. 4. Spiniform microtriches along margin of bothridium. 5. Spiniform microtriches covering external surfaces of bothridia.

\section{RESULTS}

Among the 5 species examined, the configuration, dimensions, and distributional patterns of microtriches on the scolex, neck, and strobila did not vary intraspecifically. Substantial in- terspecific differences, particularly in the tegument of the holdfast, were evident. Specimens of $T$. affinis (Figs. 1-5), T. laccocephalus (Figs. 6-9), and T. filiformis (Figs. 10-22) were found to have species-specific patterns of distribution for papilliform, filiform, and spiniform microtriches that were restricted to par-
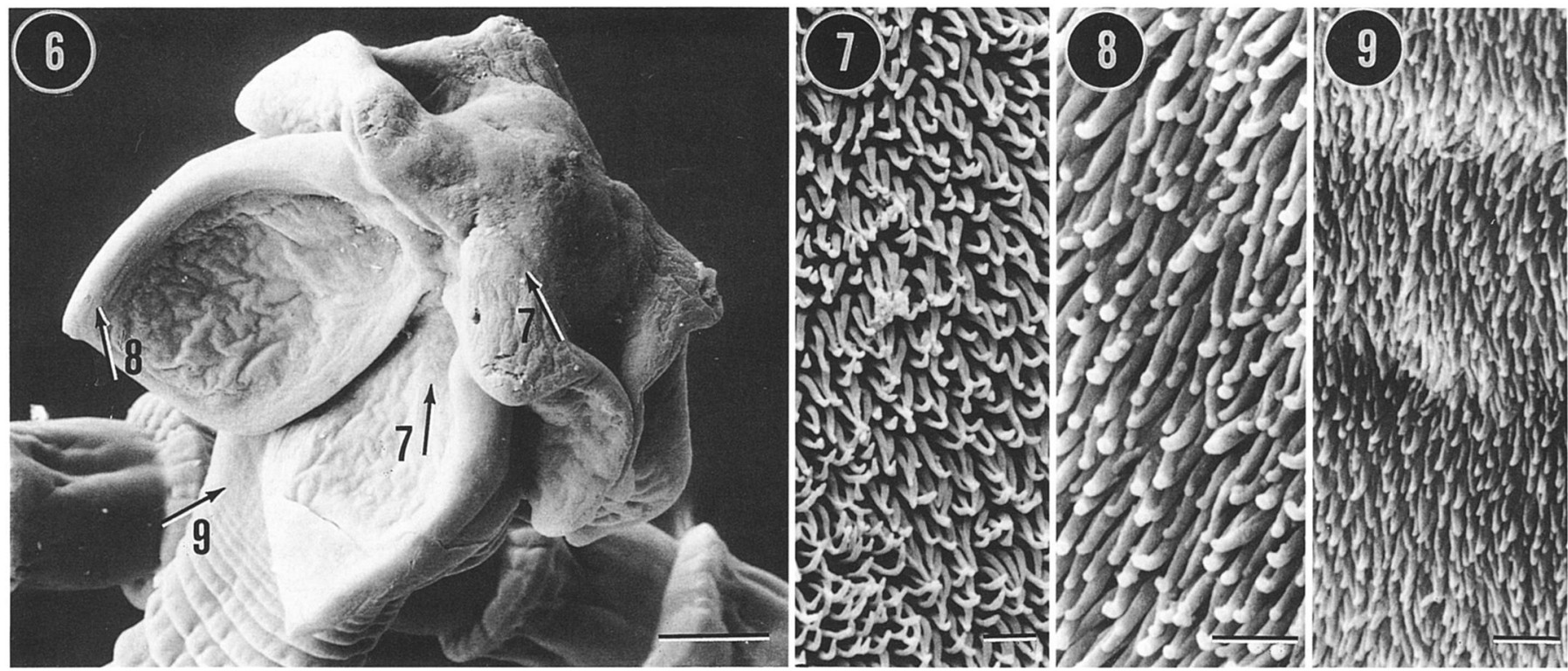

Figures 6-9. Tetrabothrius laccocephalus (scale bars $=100 \mu \mathrm{m}$ for Fig. 6; $1.0 \mu \mathrm{m}$ for all other figures). 6. Scolex showing general structure and positions of high magnification views for Figures 7-9 indicated by arrows. 7. Spiniform microtriches of uniform structure on adherent surfaces, apical organ, and auricles; depicted is the adherent surface; arrow on auricle indicates region extending onto apical organ where identical microtriches occur. 8. Spiniform microtriches on the margins of the bothridia. 9. Spiniform microtriches on the neck. 
ticular regions of the scolex and strobila (Table I). All specific regions of the scolex and strobila were covered by only a single morphotype of microthrix. In contrast, microtriches were not observed on the tegument of the scolex, neck, or strobila of $T$. (Tetrabothrius) sp. (Figs. 23-26) and T. cylindraceus (Figs. 2730).

Among species of Tetrabothrius, the scolex of $T$. affinis is comparatively massive (Fig. 1), with large sucker-like bothridia but with reduced auricles and apical organ. The central to peripheral regions of the apical organ (Fig. 2) are covered with minuscule papilliform to filiform structures $(n=10) 0.14-0.20$ (0.17) in diameter. The adherent surfaces of the bothridia have a dense uniformly distributed covering of spiniform microtriches, of consistent structure and dimensions $(n=10), 0.46-0.54$ (0.51) long (Fig. 3). The tegument on the margins and outer surfaces of the bothridia (Figs. 4, 5, respectively) is densely covered with relatively long spiniform microtriches $(n=10)$, $1.20-1.63(1.46)$ in length and $0.22-0.28(0.24)$ in width. Similar spiniform microtriches were found on the neck and strobila.

Specimens of $T$. laccocephalus have a relatively robust scolex (Fig. 6), characterized by flat bothridia with muscular margins and well developed auricles and apical organ. The apical organ, distal margins of the auricles, and adherent surfaces of the bothridia are densely covered with spiniform microtriches $(n=10)$, 0.88-1.40 (1.06) long (Fig. 7). Densely and uniformly distributed long spiniform microtriches extend to the lateral muscular margin of each bothridium $(n=5)$ 1.16-1.24 (1.20) (Fig. 8). The tegument of the neck region (Fig. 9) is similar in structure to that observed on the scolex being covered with spiniform microtriches $(n=5) \quad 0.57-0.75(0.70)$ long. Microtriches on the strobila are short and papilliform toward the middle of each segment (not depicted in figure), becoming spiniform and elongate along the posterior margin, giving the posterior borders of each segment a fringed appearance.

The scolex of $T$. filiformis has flattened, muscular bothridia and well developed auricles and apical organ (Figs. 10, 11). The apex of the apical organ has densely packed papilliform to short filiform microtriches $(n=10) 0.17-0.23(0.20)$ in diameter (Fig. 12 at center; Fig. 13 on lateral field) that become reduced in number laterally and somewhat elongate and filiform, measuring $(n=5) \quad 0.65-0.78(0.71)$ in length (Fig. 14 on lateral margins). Laterally, between the bothridia (Fig. 15), the filiform microtriches are evenly but not densely distributed. The adherent surfaces of the bothridia (Fig. 16) have short, blade-like, spiniform microtriches $(n=10), 0.70-1.05(0.86)$ in length, possibly arranged in linear rows. The external surfaces of the bothridia (Fig. 17) have a dense covering of slender spiniform microtriches $(n=5), 0.78-0.99(0.87)$ in length. The distal margins of the auricles (Fig. 18) have a dense covering of spiniform microtriches measuring $(n=5)(1.07-1.19)(1.14)$ long. The craspedote strobila (Fig. 19) has a highly defined distribution of microtriches of 2 distinct morphotypes (Fig. 20). Those on the mid-surface region are pad-like and papilliform, measuring (n = 10) $0.21-0.33(0.27)$ in diameter (Fig. 21); elongate spiniform microtriches measuring $(n=15)$ 1.15-1.94 (1.37) extend posteriad along the posterior margin of each segment (Fig. 22).

Microtriches were not observed on the scolex and strobila of T. (Tetrabothrius) sp. (Figs. 23-26) and T. cylindraceus (Figs. 27-30). The tegument appeared intact with particles of debris and bacteria on the surface but otherwise not apparently altered due to fixation or processing (Figs. 25, 26, 29, 30).

\section{DISCUSSION}

Detailed studies of the structure of the scolex among species of Tetrabothrius have included those by Spätlich (1909), Baer (1954), Rees (1956), and Andersen and Lysfjord (1982). Meristic and gross morphological aspects of the holdfasts among those species examined in the current study have been documented previously (Baer, 1954; Temirova and Skriabin, 1978) and agreed with observations from the current study. However, structural characteristics evident at high magnification with SEM have not been considered.

In agreement with other tetraphyllideans, including trypanorhynchs, that have been examined with SEM, intraspecific variation was not apparent, but interspecific variation was notable (Caira, 1990, 1992; Caira and Ruhnke, 1990, 1991; Richmond and Caira, 1991; Ruhnke, 1993, 1994). These authors have suggested that the scope of intraspecific variation, if present, may be fully documented in small samples of specimens. However, the results of the current study, particularly with respect to observations of $T$. cylindraceus and $T$. (Tetrabothrius) sp., indicate that this conclusion should be regarded with caution.

Spiniform microtriches were the most commonly occurring type (Table I). This morphotype appeared relatively similar in structure among taxa, although interspecific differences in size and density were apparent. In specimens of $T$. laccocephalus, spiniform structures occurred on the apical organ (apically and on the auricles), adherent surfaces, and lateral margins of the bothridia, the neck, and the posterior margins of the segments. Among specimens of $T$. filiformis, similar microtriches were distributed on the adherent and proximal regions of the bothridia, distal margins of the auricles, neck, and fringed posterior borders of the segments. Narrow spiniform microtriches in $T$. affinis were limited to the auricles and proximal surfaces of the bothridia. Blade-like spiniform microtriches were relatively rare, being present only on the adherent surfaces of the bothridia in $T$. affinis and $T$. filiformis. Papilliform structures were observed apically in $T$. affinis and $T$. filiformis and as prominent cushionlike microtriches on the surfaces of the segments in $T$. laccocephalus and $T$. filiformis. Filiform microtriches were confined to the apical region of $T$. filiformis and $T$. affinis.

The absence of microtriches on specimens of $T$. (Tetrabothrius) sp. and $T$. cylindraceus is anomalous. Specimens of these were recovered while alive and were fixed and stored in a comparable manner to the other species of Tetrabothrius from avian hosts. The tegument of these specimens was intact and otherwise did not appear to have been altered by fixation or storage. Specimens of both species were gravid, and acquisition by the host, a 25-day-old chick of Rissa tridactyla, would have been relatively recent. Thus, it is possible that development of the tegumental microtriches was incomplete or was undergoing rapid turnover in these young cestodes. In this regard, Caira and Ruhnke (1991) noted substantial changes in the pattern and distribution of microtriches during ontogeny of the scolex in Calliobothrium verticillatum (Rudolphi, 1819).

In contrast, specimens of $T$. filiformis and $T$. laccocephalus were also collected from recently infected hosts (Hoberg, 1987) 

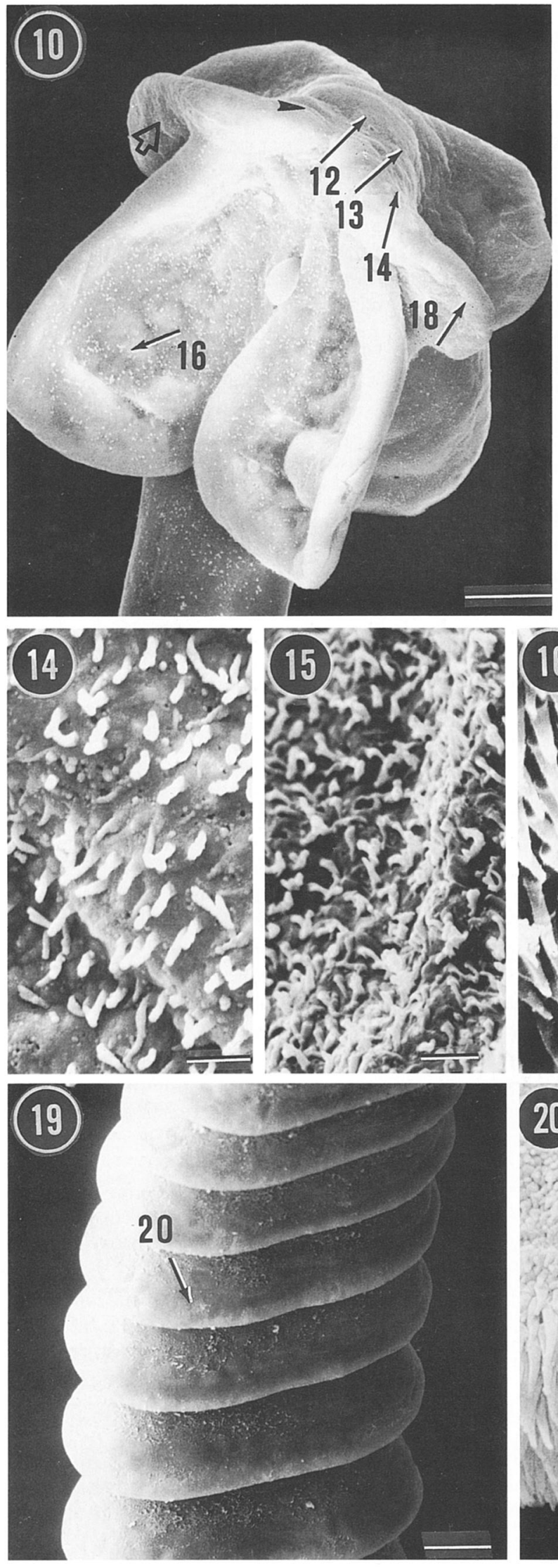

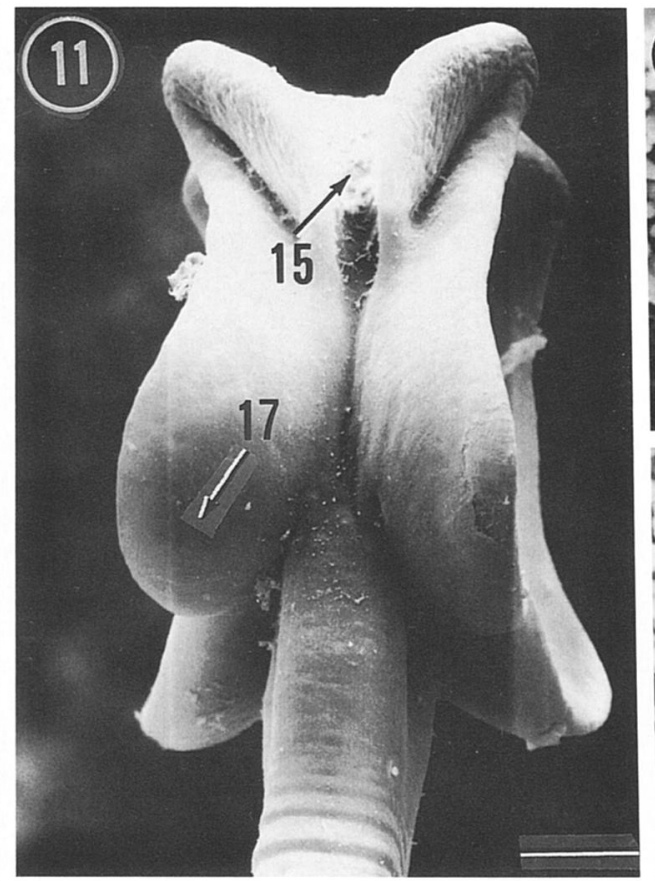

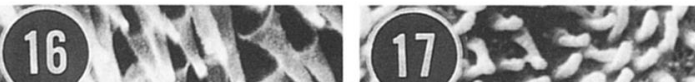

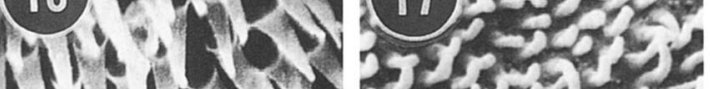
$1(1)+2525=$

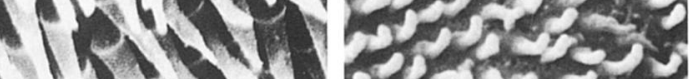

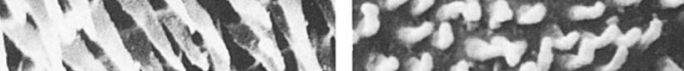
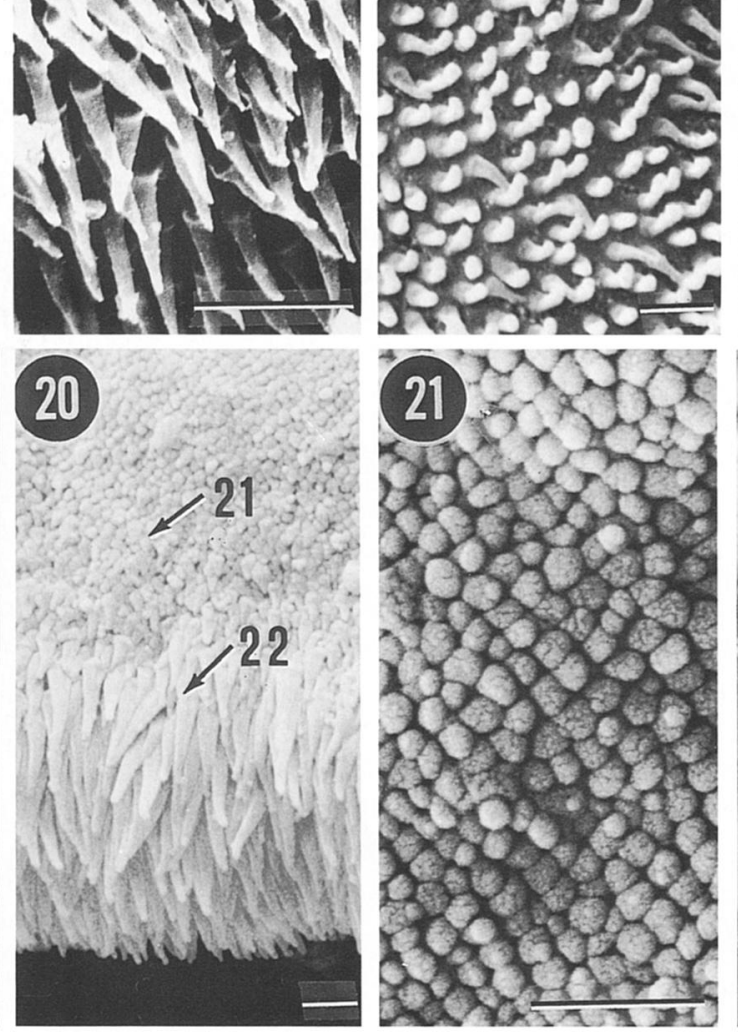

(12) 300 की athinges: $\$ 20,500$

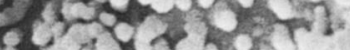
SE $<x+25$

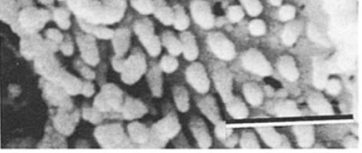

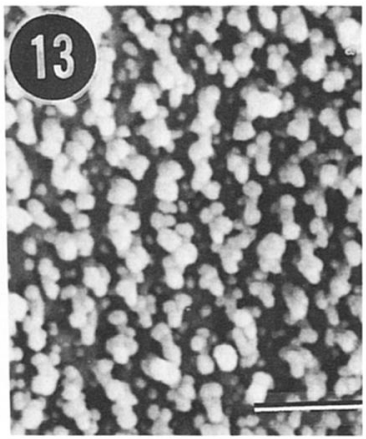

(1)

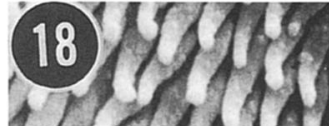
- rar mom
and

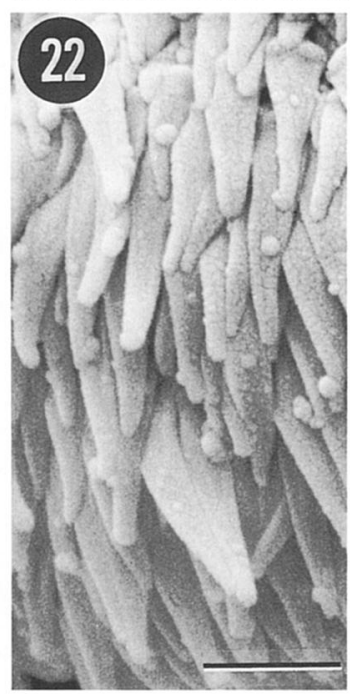



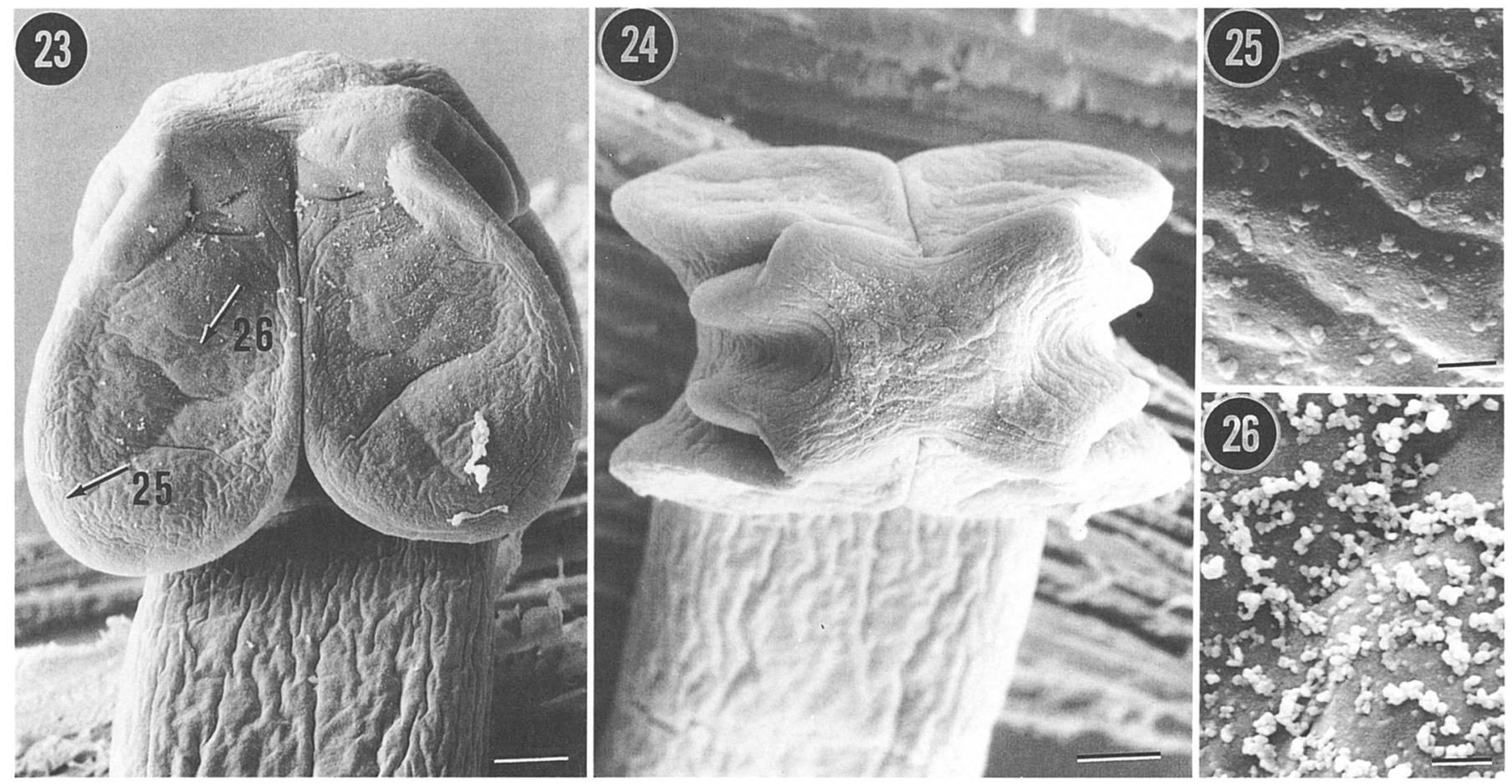

Figures 23-26. Tetrabothrius (Tetrabothrius) sp. (scale bars $=50 \mu \mathrm{m}$ for Figs. 23 and $24 ; 1.0 \mu \mathrm{m}$ for Figs. 25 and 26). 23. Scolex in dorsoventral view showing positions for Figures 25 and 26 indicated by arrows. 24. Scolex in apical view showing well developed apical organ. 25. Margin of bothridium showing tegument lacking microtriches. 26. Adherent surface of bothridium showing tegument lacking microtriches.

and microtriches were fully developed. Consequently, the absence of microtriches on specimens of $T$. cylindraceus and $T$. (Tetrabothrius) sp. cannot be readily explained and may suggest that intraspecific variation could influence observations in some circumstances. Additional freshly collected material from another source will be necessary to determine whether or not the observations are an artifact of fixation and preparation.

The systematic value of patterns of distribution and configuration of the microtriches among species of Tetrabothrius is currently unrevealing. The speciose genus Tetrabothrius has been partitioned into 4 subgenera (Murav'eva, 1975; Temirova and Skriabin, 1978), but a phylogenetic basis for recognition of these groups has yet to be established (Hoberg, 1989, 1994). The structure and distribution of microtriches among $T$. (Oriana) affinis, T. (Oriana) filiformis, and T. (Culmenamniculus) laccocephalus are highly variable and no patterns were recognized among these species that could contribute to differentiation at the subgeneric level. However, additional study is necessary to establish whether blade-like spiniform microtriches on the adherent surfaces of the bothridia and filiform structures confined to the apex of the apical region may represent characters unique for T. (Oriana) spp. Microtriches occurring on the scolex also were not apparently correlated with host group. Tetrabothrius affinis is a characteristic cestode of cetaceans, whereas $T$. filiformis and T. laccocephalus occur among Procellariiformes and $T$. (Tetrabothrius) sp. and T. cylindraceus occur in Charadriiformes. A broader representation of Tetrabothrius spp. is required to evaluate fully the hypotheses that patterns and forms of microtriches may be influenced by intraspecific variation, and that specific types and distribution of microtriches may provide resolution of systematics at the subgeneric level.

A tetraphyllidean ancestry for the tetrabothriids (Baer, 1954; Euzet, 1959) or inclusion of the family within the Tetraphyllidea has been postulated (Hoberg, 1987, 1989; Brooks et al., 1991). Some derived onchobothriids have been considered the probable sister-group based on postlarval ontogeny and some structural characteristics of the strobilar stages (Hoberg, 1987). Caira (1990) and Caira and Ruhnke (1990, 1991) suggested that microthrix structure was a significant systematic character among the Onchobothriidae. Based on unique patterns of distribution (on the holdfast), they postulated monophyly for some inclusive groups of genera. Among 17 genera of the onchobothriids, great

FIGURES 10-22. Tetrabothrius filiformis (scale bars $=50 \mu \mathrm{m}$ for Figs. 10,11 , and $19 ; 1.0 \mu \mathrm{m}$ for other figures). 10. Scolex showing general structure in dorsoventral view, with well developed auricles (open arrow) and apical organ (center indicated by pointer), and positions of high magnification views for Figures 12-14, 16, and 18 indicated by arrows. 11. Scolex in lateral view showing positions tor Figures 15 and 17 indicated by arrows. 12. Papilliform to short filiform microtriches at center of apical organ. 13. Short filiform microtriches in the field lateral to the central region of the apical organ. 14. Elongate filiform microtriches on lateral margins of the apical organ. 15. Filiform microtriches situated between the bothridia. 16. Spiniform microtriches on the adherent surfaces of the bothridia. 17. Slender spiniform microtriches on the external surfaces of the bothridia. 18. Spiniform microtriches on the distal margins of the auricles. 19. Highly craspedote strobila showing position of Figure 20 indicated by arrow. 20. Posterior margin of segment showing overall distributions of papilliform and spiniform microtriches and positions of Figures 21 and 22 indicated by arrows. 21. Detail of cushion-like papilliform microtriches in the medial region of the segment. 22. Detail of spiniform microtriches along posterior margin of segment. 

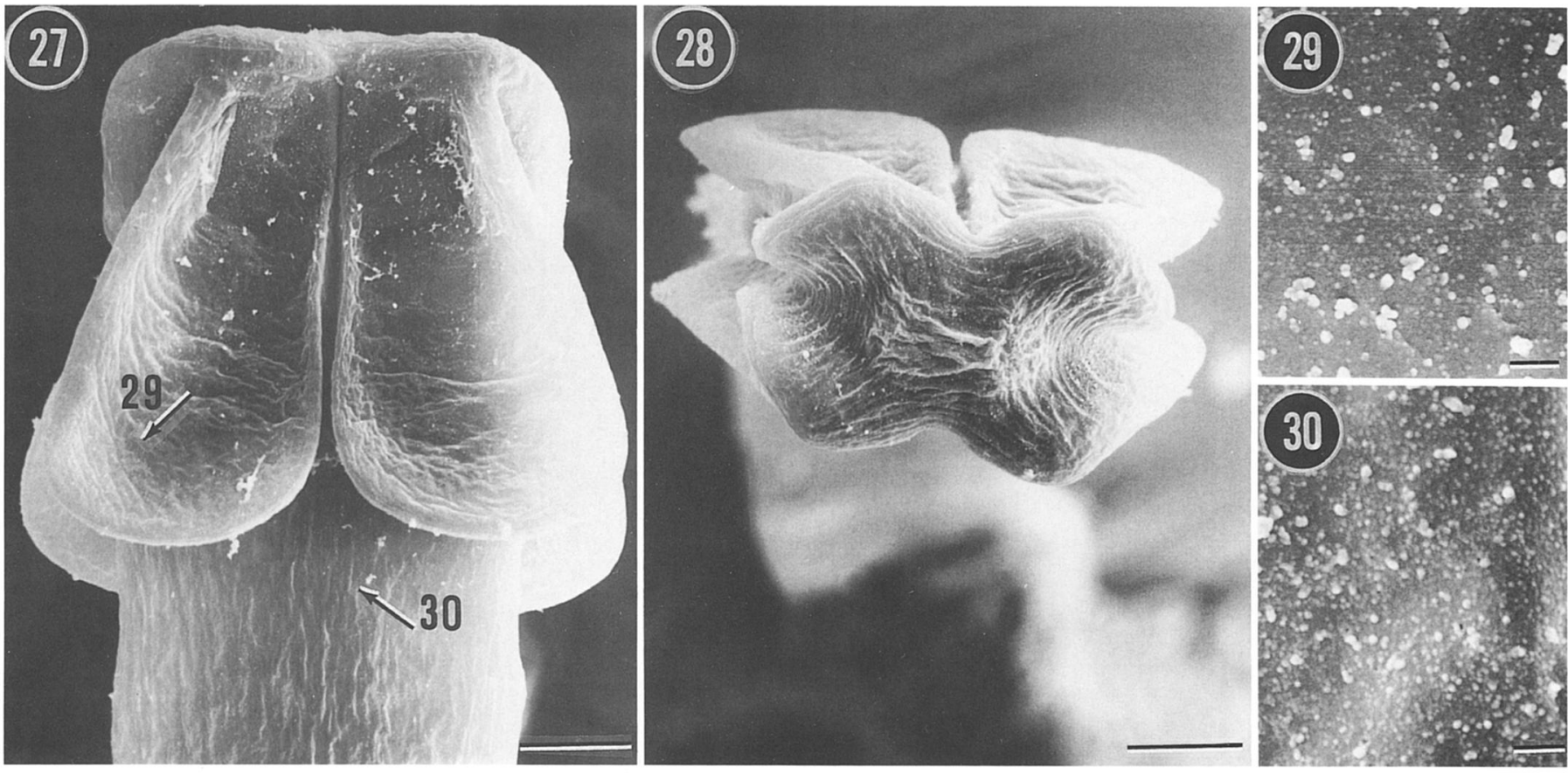

Figures 27-30. Tetrabothrius (Culmenamniculus) cylindraceus (scale bars $=50 \mu \mathrm{m}$ for Figs. 27 and $28 ; 1.0 \mu \mathrm{m}$ for Figs. 29 and 30 ). 27. Scolex in dorsoventral view showing positions for Figures 29 and 30 indicated by arrows. 28. Scolex in apical view showing well developed apical organ. 29. Adherent surface of bothridium showing tegument lacking microtriches. 30. Neck showing tegument lacking microtriches.

intraspecific uniformity was accompanied by substantial interspecific differences in structure and distribution of the microtriches (Caira, 1990, 1992). Similarly, these general patterns were found among the species of Tetrabothrius examined by us.

Spiniform, filiform, and papilliform types of microtriches are represented among the tetrabothriids, onchobothriids, and phyllobothriids (Caira and Ruhnke, 1990; Ruhnke, 1994). Among those onchobothriids that have been examined, all regions of the scolex were covered with at least 1 form of microthrix (Caira, 1990). In contrast, among the tetrabothriids considered here, typically a specific morphotype was restricted to a limited region

TABLE I. Distribution and form of microtriches among some species of Tetrabothrius.

\begin{tabular}{|c|c|c|c|c|c|}
\hline Region & $\begin{array}{c}T . \\
\text { (Tetra- } \\
\text { bothrius) } \\
\text { sp. }\end{array}$ & $\begin{array}{c}T . \\
\text { (Oriana) } \\
\text { affinis }\end{array}$ & $\begin{array}{c}T . \\
\text { (Oriana) } \\
\text { fili- } \\
\text { formis }\end{array}$ & $\begin{array}{c}T . \\
\text { (Culmen- } \\
\text { amni- } \\
\text { culus) } \\
\text { lacco- } \\
\text { cephalus }\end{array}$ & $\begin{array}{c}T . \\
\text { (Culmen- } \\
\text { amni- } \\
\text { culus) } \\
\text { cylindra- } \\
\text { ceus }\end{array}$ \\
\hline \multicolumn{6}{|c|}{ Scolex, bothridia } \\
\hline Apical & Absent & $\mathrm{P}^{*}, \mathrm{~F}^{\dagger}$ & $P, F$ & Sł & Absent \\
\hline Adherent & Absent & S & $\mathrm{S}$ & $\mathrm{S}$ & Absent \\
\hline Proximal & Absent & S & $\mathbf{S}$ & S & Absent \\
\hline Auricles & Absent & $\mathrm{S}$ & $\mathrm{S}$ & $\mathrm{S}$ & Absent \\
\hline \multicolumn{6}{|l|}{ Strobila } \\
\hline Neck & Absent & $S$ & - & $\mathbf{S}$ & Absent \\
\hline Segment & Absent & $\mathbf{S}$ & $P, S$ & $P, S$ & - \\
\hline
\end{tabular}

${ }^{*} \mathrm{P}=$ papilliform.

$\dagger=$ filiform.

$\ddagger \mathrm{S}=$ spiniform. of the scolex (or segment) and 2 or more forms never occurred in the same region. Filiform to papilliform structures were found apically on scolices of $T$. affinis and $T$. filiformis and appeared similar to those described for Calliobothrium spp. (Caira and Ruhnke, 1990, 1991) and Phyllobothrium spp. (Whittaker et al., 1985). Blade-like spiniform microtriches occurring on the adherent surface of the bothridia in $T$. affinis and $T$. filiformis may be similar to those known for Calliobothrium pritchardae Caira and Ruhnke, 1990 (Caira and Ruhnke, 1990). The widespread occurrence of these basic morphotypes may constitute the plesiomorphic condition for these groups of cestodes, although distributional patterns on the tegument may have systematic value (Caira, 1990). Absence of microtriches has not been observed among the onchobothriids but was reported for the apical region of some lecaniacephalids (Nock and Caira, 1988; Caira, 1990).

Microtriches have been widely reported among all major orders of Eucestoda. These are present on the scolices and strobila of representatives of most groups that have been examined with SEM. Papilliform, spiniform, and filiform structures have been variously reported among the Pseudophyllidea (Andersen, 1975; Granath et al., 1983; Yazaki et al., 1990), Cyclophyllidea (Berger and Mettrick, 1971; Ubelaker et al., 1973), and the Proteocephalidea (Thompson et al., 1980). The palmate form, apparently unique to the trypanorhynchs (Whittaker et al., 1985; Richmond and Caira, 1991; Shields, 1985), and the "corn cob" type found in Orygmatobothrium musteli (Van Beneden, 1850) (Whittaker and Carvajal, 1980), and 2 species of Paraorygmatobothrium Ruhnke, 1994 may constitute apomorphic characters (Caira, 1990; Richmond and Caira, 1991; Ruhnke, 1994). Additionally, apparently unique serrated microtriches were recognized as the basis for establishing the latter genus (Ruhnke, 1994). 
Variation in microthrix structure and distribution has been applied to the systematics of tetraphyllideans, where it is apparent that some morphotypes may be restricted to particular taxonomic groups (Ruhnke, 1994). However, the broad distribution of a variety of morphotypes among disparate orders including the Pseudophyllidea, Cyclophyllidea, and Tetraphyllidea, in conjunction with recent phylogenetic hypotheses for the Eucestoda (Brooks et al., 1991), suggests that the basic spiniform, filiform, and papilliform microtriches are symplesiomorphic among cestodes.

\section{ACKNOWLEDGMENTS}

We thank David O'Neil and Margaret Horne for their skillful operation of the SEM and for the preparation of publication micrographs. Specimens of $T$. affinis were kindly provided by Leo Margolis of the Pacific Biological Station, Nanaimo, British Columbia. Material from greater shearwaters was provided by Peter Ryan of the Percy FitzPatrick Institute for African Ornithology, University of Cape Town. Field studies at Talan Island, USSR (by E.P.H.) were conducted under the Interacademy Exchange Program of the National Academy of Sciences; logistical support in Russia was provided by Alexander Ia. Kondratiev and the Institute of Biological Problems of the North, Magadan, Russia (Russian Academy of Sciences).

\section{LITERATURE CITED}

ANDERSEN, K. 1975. Comparison of the surface topography of three species of Diphyllobothrium (Cestoda, Pseudophyllidea) by scanning electron microscopy. International Journal for Parasitology 5: 293-300.

-, AND S. LYSFJORD. 1982. The functional morphology of the scolex of two Tetrabothrius Rudolphi 1819 species (Cestoda: Tetrabothriidae) from penguins. Zeitschrift für Parasitenkunde 67: 299-307.

BAER, J. G. 1954. Revision taxonomique et étude biologique des cestodes de la famille des Tetrabothriidae, parasites d'oiseaux de haute mer et de mammifêres marins. Mémoires Université Neuchatel 1: $1-121$.

Berger, J., AND D. F. MeTTRICK. 1971. Microtrichial polymorphism among hymenolepidid tapeworms as seen by scanning electron microscopy. Transactions of the American Microscopical Society 90: 393-403.

Brooks, D. R., E. P. Hoberg, AND P. J. Weekes. 1991. Preliminary phylogenetic systematic analysis of the major lineages of the Eucestoda Southwell, 1930 (Platyhelminthes: Cercomeria). Proceedings of the Biological Society of Washington 104: 651-658.

CAIRA, J. N. 1990. Scolex microtriches as systematic characters in the Onchobothriidae. International Congress of Parasitology VII. Specific and supraspecific systematics. Bulletin Société Francaise de Parasitologié 8: 212.

- 1992. Verification of multiple species of Pediobothrium in the Atlantic nurse shark with comments on the Australasian members of the genus. Journal of Parasitology 78: 289-308.

- , AND T. R. RUHNKE. 1990. A new species of Calliobothrium (Tetraphyllidea: Onchobothriidae) from the whiskery shark, Furgaleus macki, in Australia. Journal of Parasitology 76: 319-324.

$\longrightarrow$, AND - 1991. A comparison of scolex morphology between the plerocercoid and the adult of Calliobothrium verticillatum (Tetraphyllidea: Onchobothriidae). Canadian Journal of Zoology 69: 1484-1488.

EuZET, L. 1959. Recherches sur les cestodes tétraphyllides des sélaciens des côtes de France. Thèses Université de Montpellier. Caussee, Graille et Castelneau, Montpellier, France, 263 p.

Granath, W. O. JR., J. C. LeWIS, AND G. W. Esch. 1983. An ultrastructural examination of the scolex and tegument of Bothriocephalus acheilognathi (Cestoda: Pseudophyllidea). Transactions of the American Microscopical Society 102: 240-250.

Hoberg, E. P. 1987. Recognition of larvae of the Tetrabothriidae (Eucestoda): Implications for the origin of tapeworms in marine homeotherms. Canadian Journal of Zoology 65: 997-1000.

- 1989. Phylogenetic relationships among genera of the Tetrabothriidae (Eucestoda). Journal of Parasitology 75: 617-626.

- 1994. Keys to the genera and subgenera of the family Tetrabothriidae. In CIP keys to the cestode parasites of vertebrates, $\mathrm{L}$. F. Khalil, A. Jones, and R. Bray (eds.). Commonwealth Agricultural Bureaux, International Institute of Parasitology, St. Albans, U.K., p. 295-304.

Kennedy, J. R., R. W. Williams, AND J. P. Gray. 1989. Use of Peldri II (a fluorocarbon solid at room temperature) as an alternative to critical point drying for biological tissues. Journal of Electron Microscopy Technique 11: 117-125.

MuRAv'EvA, S. I. 1975. Morfologo-anatomicheskie osnovy sistematiki tetrabotriid. Problemy Parazitologii 2: 49.

NoCK, A. M., AND J. N. CAIRA. 1988. Disculiceps galapagoensis n. sp. (Lecaniacephalidea: Disculicepitidae) from the shark, Carcharhinus longimanus with comments on D. pileatus. Journal of Parasitology 74: 153-158.

REEs, G. 1956. The scolex of Tetrabothrius affinis (Lönnberg) a cestode from Balaenoptera musculus L., the blue whale. Parasitology 46: 425-442.

Richmond, C., AND J. N. CAIRA. 1991. Morphological investigations into Floriceps minacanthus (Trypanorhynca: Lacistorhynchidae) with analysis of the systematic utility of scolex microtriches. Systematic Parasitology 19: 25-32.

RuHNKE, T. R. 1993. A new species of Clistobothrium (Cestoda: Tetraphyllidea), with an evaluation of the systematic status of the genus. Journal of Parasitology 79: 37-43.

. 1994. Paraorygmatobothrium barberi n. g., n. sp. (Cestoda: Tetraphyllidea), with amended descriptions of two species transferred to the genus. Systematic Parasitology 28: 65-79.

SHIELDS, J. D. 1985. Surface morphology and description of Otobothrium kurisi new species (Cestoda: Trypanorhyncha) from a hammerhead shark, Sphyrna lewini. International Journal for Parasitology 15: 635-643.

SPÄTLICH, W. 1909. Untersuchungen über Tetrabothrien. Ein Beitrag zur Kenntnis des Cestoden Körpers. Zoologische Jahrbucher Abteilung für Anatomie und Ontogenie der Tiere 28: 539-594.

Temirova, S. I., AND A. S. Skriabin. 1978. Tetrabotriaty i mezotsestoidaty lentochnye gel'minty ptits i mlekopitaiushchikh. Osnovy Tsestodologii 9. Akad. Nauk SSSR, Izdatel'stvo Nauka Moskva.

Thompson, R. C. A., A. R. Hayton, and L. P. Jue Sue. 1980. An ultrastructural study of the microtriches of adult Proteocephalus tidswelli (Cestoda: Proteocephalidea). Zeitschrift für Parasitenkunde 64: 95-111.

Ubelaker, J. E., V. F. Allison, and R. D. Specian. 1973. Surface topography of Hymenolepis diminuta by scanning electron microscopy. Journal of Parasitology 59: 667-671.

Whittaker, F. H., R. P. Apkarian, B. Curless, and J. G. Carvajal. 1985. Scanning electron microscopy of the scolices of the cestodes Parachristianella monomegacantha Kruse, 1959 (Trypanorhyncha) and Phyllobothrium sp. Beneden, 1849 (Tetraphyllidea). Journal of Parasitology 71: 376-381.

- AND J. G. Carvajal. 1980. Scanning electron microscopy of scolices of some cestodes from elasmobranchs. Proceedings of the Helminthological Society of Washington 47: 256-259.

YAZAKI, S., S. FuKumoto, AND J. MAEJIMA. 1990. Cytoskeletal construction and alteration of microtriches of Diphyllobothrium hottai, during early developmental stages. Japanese Journal of Parasitology 39: $165-171$. 